\title{
SIZE-STRUCTURED SPATIAL PATTERNS AS A MEASURE OF LARVAL DISPERSAL AND EMIGRATION
}

\author{
Douglas F. Markle1
}

\begin{abstract}
Size-structured spatial patterns in larvae of 2 sucker and 3 minnow species are described from fixed-site sampling in Upper Klamath Lake, Oregon, and are used to demonstrate patterns of size-based losses downstream and retention in the lake. The smallest larvae of shortnose suckers (Chasmistes brevirostris), Lost River suckers (Deltistes luxatus), and tui chubs (Siphateles bicolor) were least likely to be found in Lake Ewauna, a downstream catchment; yet the proportion of larger larvae downstream was often substantial, $20 \%-40 \%$ of a size class. In contrast, the smallest larvae of blue chubs (Klamathella coerulea) and fathead minnows (Pimephales promelas) were least likely to be found in restoration marshes. For these 2 species, interannual differences in spatial size-structuring was variable, with larger size classes being found in high proportions in restoration marshes in some years but not in others. These patterns may be indicative of substantial emigration from Upper Klamath Lake, in the case of suckers and tui chubs, and of variable use of restoration marshes by larger blue chubs and fathead minnows. Although this and other approaches can provide insight into larval emigration and movement, spatially intensive sampling and knowledge of circulation patterns may allow for more rigorous estimates of larval movements.
\end{abstract}

RESUMEN.-Describimos los patrones espaciales de las larvas estructuradas de acuerdo a su tamaño de 2 especies de peces de la familia Catostomidae y 3 especies de peces de la familia Cyprinidae mediante el muestreo en sitios fijos del lago Upper Klamath, y los utilizamos para demostrar patrones en las pérdidas de ciertos tamaños aguas abajo y su retención en el lago. Las larvas más pequeñas de Chasmistes brevirostris, Deltistes luxatus y Siphateles bicolor se encontraron menos frecuentemente en el lago Ewauna, una cuenca aguas abajo; sin embargo, la proporción de larvas más grandes aguas abajo fue a menudo alta, con un 20\%-40\% de una categoría de tamaño. Por el contrario, las larvas más pequeñas de Klamathella coerulea y de la carpita cabezona (Pimephales promelas) fueron menos comunes en las ciénagas en restauración. En estas especies, hubo variación interanual en la estructura espacial por tamaños, en la que categorías de mayor tamaño ocurrieron en proporciones elevadas en las ciénagas en restauración durante ciertos años pero no en otros años. Estos patrones podrían indicar una emigración substancial del lago Upper Klamath en el caso de los peces de la familia Catostomidae y de Siphateles bicolor, o podrían indicar el uso variable que larvas grandes de Klamathella coerulea y de las carpitas cabezonas le dan a las ciénagas en restauración. Aunque tanto este como otros enfoques pueden brindar conocimiento sobre la emigración y el movimiento de las larvas, se podrían obtener estimados más precisos sobre los movimientos de las larvas a través del conocimiento de los patrones de circulación y del muestreo espacialmente intensivo.

The huge fecundity of most teleosts requires that a majority die before reaching maturation, and the most persistent pattern is that mortality occurs in early life stages (Houde 1997) and can easily exceed 99\% (Houde 2002). Efforts to partition sources of early mortality have been hindered by analytical and sampling problems (Houde and Bartsch 2009). One problem is that dispersive losses can equal losses from natural mortality (Taggart and Leggett 1987, Helbig and Pepin 1998b), and unless sampling is spatially and temporally extensive and intense, such losses can be undetected (Houde and Bartsch 2009).

At its simplest, larval dispersal and emigration have age- or size-structured patterns, in that the youngest (smallest) larvae will be near the spawning source and larger larvae will either be retained in population-appropriate nursery habitats or found in inappropriate habitats. In the context of the membervagrant hypothesis (Sinclair 1988), retained larvae (members) contribute to the parent population, and those that are not retained (vagrants) contribute to sink populations or are lost to the species. Spatial patterns consistent with the member-vagrant hypothesis are more easily detected when spawning sites (and small larvae) are spatially restricted, when nursery areas accumulate one or more size classes, and when movement is unidirectional. Most freshwater fish larvae drift at night (Brown and Armstrong 1985), so the latter is likely true for small larvae if current direction is unidirectional.

${ }^{1}$ Department of Fisheries and Wildlife, 104 Nash Hall, Oregon State University, Corvallis, OR 97331-3803. E-mail: douglas.markle@oregonstate.edu 


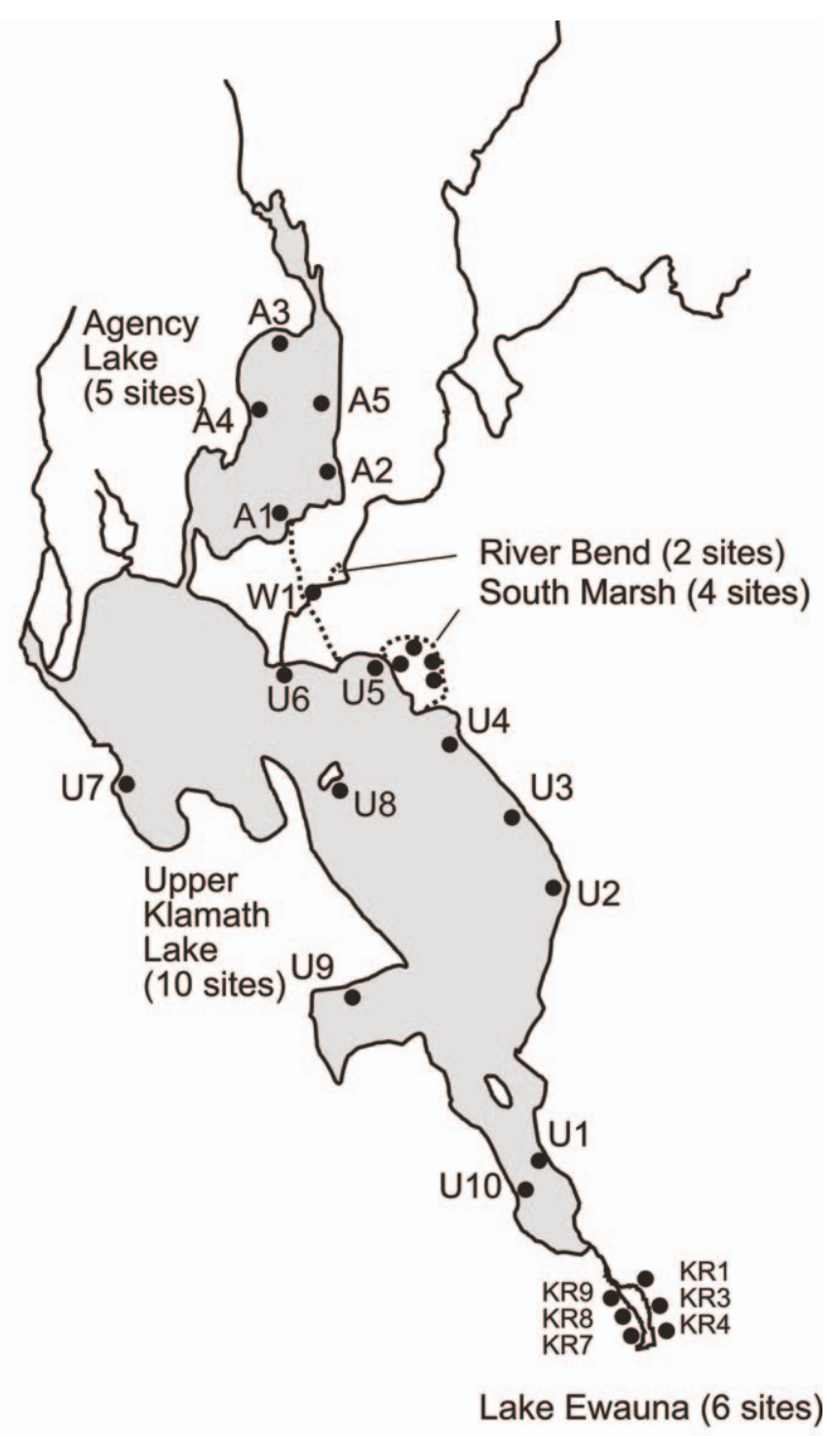

Fig. 1. Map of Upper Klamath Lake, Oregon, showing locations of fixed site samples, 2005-2009. Dashed line through W1 marks the approximate shoreline after 2007; other dashed lines surround restoration marshes.

Markle et al. (2009) suggested that in Upper Klamath Lake, Oregon, relative abundance of young-of-the-year juveniles of the 5 most abundant species was related to their location in the lake. In August, when most juveniles were close to the lake outlet, abundance was lower than when most were further from the lake outlet. Markle et al. also suggested that movements and emigration of larvae may be a driver of this pattern. In the following text, we examine 5 years of size-structured spatial patterns of larvae and early juveniles of the 5 species com- mon to the shoreline of Upper Klamath Lake: shortnose sucker (Chasmistes brevirostris), Lost River sucker (Deltistes luxatus), blue chub (Klamathella coerulea), tui chub (Siphateles bicolor), and fathead minnow (Pimephales promelas). Data are from fixed-site index sampling of larvae along the shoreline of Upper Klamath Lake, the shoreline of Agency Lake, the mouth of the Williamson River, restoration marshes, and a downstream area, Lake Ewauna (Fig. 1). Our results illustrate the types of size-structured spatial patterns that can be found in larvae and 


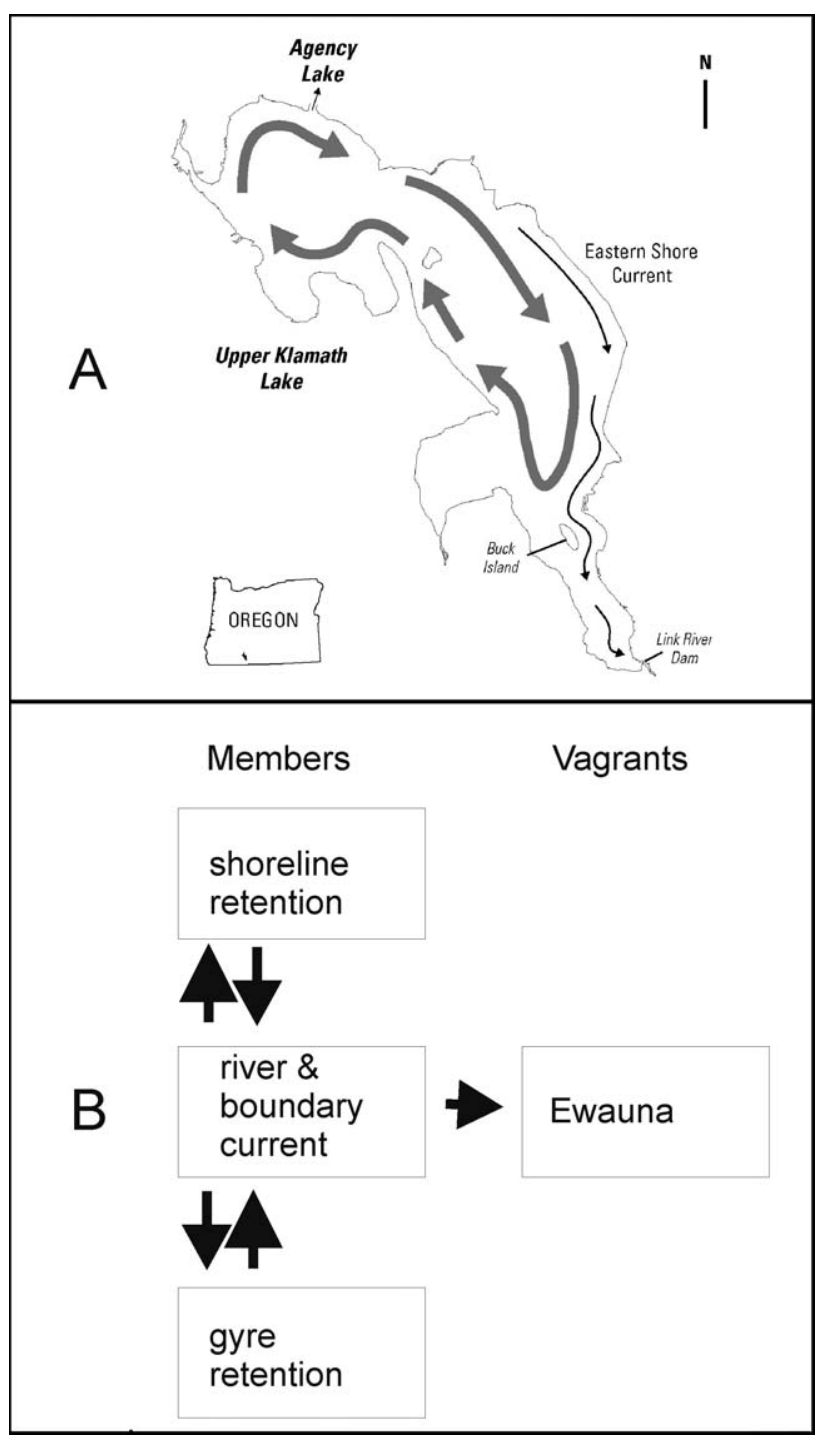

Fig. 2. A, General pattern of wind-driven circulation in Upper Klamath Lake, Oregon, showing the 2007 shoreline. Gyre shown by large arrows; eastern boundary current shown by narrow arrows. B, Schematic of the advection and dispersion relationships among areas for member and vagrant larvae. Arrows indicate direction of advection/dispersion originating with the primary transport of the river and eastern boundary current.

may be used to infer overall retention in the lake, size classes retained in particular areas such as in-lake marshes, size-based losses downstream, and interannual differences. Shortcomings in the use of size rather than age in the sampling, approaches for better sampling, and caveats in interpretation are discussed.

\section{Circulation and Larval Retention}

The topography surrounding Upper Klamath Lake (UKL) channels wind over a northwest to southeast axis and, under prevailing northwest winds, the residual flow is a clockwise gyre north of Buck Island (Wood et al. 2008). The relatively small fraction of the lake volume that exits the lake is confined to a narrow boundary current along the eastern shoreline that passes east of Buck Island (Fig. 2A). Winds may also reverse from the prevailing direction and stall the prevailing circulation pattern, or, if a reversal lasts longer than one day, reverse the direction of circulation (Markle et al. 2009, Wood 
2009). Other variables, such as lake elevation and inflow and discharge from the lake at Link River Dam, may also affect circulation patterns (Wood 2009).

In fall 2007, the Nature Conservancy began delta restoration at the mouth of the Williamson River and removed dikes around former agricultural land. The pre-2007 shoreline is depicted in Figure 1 with the approximate boundary of the new shoreline shown as a dashed line through site W1 (Fig. 1). The northern embayment of Upper Klamath Lake, known as Agency Lake, is integrated now with the rest of the lake. Removal of the dikes did not materially change the large-scale circulation patterns but did alter the pathways that bring larvae from the river into the lake (Wood et al. in press). The outlets of the lake are Link River Dam and the "A" Canal. Link River connects to Lake Ewauna and the Keno Reach of the Klamath River, an area with very poor water quality - the water often becoming anoxic in late summer (Sullivan et al. 2010). The "A" Canal is an irrigation diversion with a capacity of $32.6 \mathrm{~m}^{3} \cdot \mathrm{s}^{-1}$ (1150 cfs). From 1991 to 2000 , annual irrigation diversion through the "A" Canal was about $20 \%$ of the outflow of the lake (Rykbost and Todd 2002); however, in summer it can be over $50 \%$ of the outflow (U.S. Bureau of Reclamation Hydrology Database, http://www.usbr.gov/mp/kbao/ operations/water/index.html).

Klamath sucker larvae have strong diel habitat differences. During daylight, larvae are in slack water areas out of the current (Cooperman and Markle 2003), but at night they often drift (Pavlov 1994, Cooperman and Markle 2003). This behavior and the prevailing currents can lead either to emigration out of the lake via the eastern boundary current or to retention in the lake, either in the gyre or in the shoreline marshes (Markle et al. 2009). Given this system, the member-retention mechanism probably works as a dynamic of advection/dispersion of larvae between transporting currents (river and boundary current) and the shoreline or the gyre, and vagrancy would be enhanced with longer residency in the transporting currents or stronger currents (Fig. 2B). Good retention would be characterized by spatial structuring with older/ larger larvae found throughout the system, while poor retention would be characterized by spatial structuring with all young/small larvae upstream (Williamson River mouth) and all older/larger larvae downstream (Lake Ewauna). In the con- text of this paper, vagrants are those larvae that leave Upper Klamath Lake for Lake Ewauna. Depending on the species, these vagrants may contribute to other sustainable populations or to sink populations or may be lost to the species.

\section{Methods}

Sampling from 2005 to 2009 began the first full week of April and continued through late July, with samples collected every third week for a total of 6 sampling surveys. Sampling was spatially extensive. In Upper Klamath Lake, 2 samples were collected from each of 10 fixed sites from 2005 to 2007 (Fig. 1). The Williamson River mouth (WRM) changed because of restoration in late 2007. Site U6, the former site of the river mouth, and site $\mathrm{W} 1$, the new river mouth site, were both sampled in 2008 and 2009; but only site W1 was used to characterize the river mouth and U6 was dropped from analyses. In Agency Lake, 2 samples were collected from each of 5 fixed sites; in Lake Ewauna, 1 sample was collected from each of 6 fixed sites; in the restoration marsh at River Bend, 1 sample was collected from each of 2 fixed sites; and in the restoration marsh at South Marsh, 1 sample was collected from each of 4 fixed sites (Fig. 1). Low lake elevation in late season sometimes precluded sampling at South Marsh. Water quality parameters (temperature, dissolved oxygen, $\mathrm{pH}$, and conductivity) were measured at each site using a calibrated Hydrolab Reporter Multiprobe and Surveyor 3 Display Logger or a YSI 650 MDS Display with a 600QS Sonde. Based on parameters associated with potential sublethal effects on growth in larval suckers (Terwilliger et al. 2003), we considered water quality poor when any or all of these thresholds were met: water temperature $>21.9$ ${ }^{\circ} \mathrm{C}$, dissolved oxygen $<5.1 \mathrm{mg} \cdot \mathrm{L}^{-1}$, or $\mathrm{pH}>$ 8.9. Use of poor-water quality sites was evaluated using Strauss' linear index (Strauss 1983), which has a value of zero if sites are occupied in proportion to their availability and a range from 1 (complete selection) to -1 (complete avoidance).

A larval trawl with a $0.8 \times 1.5-\mathrm{m}$ opening and a 2.50-m-long, 1000- $\mu \mathrm{m}$ bar-mesh Nitex ${ }^{\circledR}$ net mounted on an aluminum frame with runners (LaBolle et al. 1985) was set 3-12 m offshore in water up to $1 \mathrm{~m}$ deep (range $0.2-1.0 \mathrm{~m}$ ), allowed to soak for 10 minutes, and pulled to shore with ropes. Based on preliminary work, 
TABLE 1. Species, size cut-off, and proportion of the lower $10 \%$ of the size distribution for larval suckers and minnows collected in Upper Klamath Lake, Agency Lake, restoration marshes, and Lake Ewauna, 2005-2009. $N_{10}=$ sample size for lower $10 \%$ of size distribution, SL = standard length, UKL = Upper Klamath Lake, AL = Agency Lake, $\mathrm{RM}=$ restoration marshes, and LE = Lake Ewauna.

\begin{tabular}{lccrrrr}
\hline Species & SL $(\mathrm{mm})$ & UKL & AL & RM & LE & $N_{10}$ \\
\hline Shortnose sucker & $<12.2$ & 78.0 & 1.5 & 19.1 & 1.3 & 528 \\
Lost River sucker & $<12.5$ & 73.3 & 1.6 & 23.4 & 1.6 & 124 \\
Tui chub & $<8.1$ & 58.2 & 25.8 & 9.4 & 6.6 & 213 \\
Blue chub & $<8.1$ & 25.3 & 10.2 & 1.2 & 63.3 & 2747 \\
Fathead minnow & $<7.1$ & 47.1 & 15.3 & 5.8 & 31.8 & 2732 \\
\hline
\end{tabular}

the larval trawl was effective at capturing larval fishes up to $20-25 \mathrm{~mm}$. Samples were fixed in $10 \%$ formalin and later switched to $50 \%$ isopropanol for long-term storage. Cyprinid larvae were identified using characters described by Remple and Markle (2005). Smaller catostomid larvae $(<14 \mathrm{~mm})$ were identified based on pigmentation patterns (unpublished data). A portion had intermediate patterns and were classified as unidentified suckers. Larger catostomid larvae were cleared and stained (Potthoff 1984), postWeberian vertebrae were counted, and species were assigned based on post-Weberian vertebral counts (Markle et al. 2005). Those with $>44$ vertebrae were classified as Lost River suckers, those with $<44$ as shortnose suckers, and those with 44 as unidentified suckers. There is no method for distinguishing between larval shortnose and Klamath largescale suckers, Catostomus snyderi; but based on gillraker counts of juveniles and juvenile distribution patterns, most shortnose/Klamath largescale suckers in the lake and downstream are thought to be shortnose suckers, while those in the restoration marsh at River Bend are most likely a mixed species assemblage. For convenience, we will refer to all shortnose/Klamath largescale sucker larvae as shortnose sucker larvae.

All larvae were measured to the nearest $0.1 \mathrm{~mm}$ and grouped into 1-mm bins. We categorized small larvae as the lower $10 \%$ of the size distribution, and we used their absence in an area to determine areas that might potentially accumulate larger exogenous larvae. Because of differences in these distributions, we used 2 different habitat groupings for Upper Klamath Lake, depending on whether the Williamson River mouth or restoration marshes were included. For suckers and tui chubs, spatial habitat groupings included the Williamson River mouth, Upper Klamath Lake (including Agency Lake and restoration marshes), and Lake Ewauna. For blue chubs and fathead minnows, spatial habitat groupings included Upper Klamath Lake (including Agency Lake and the mouth of the Williamson River), restoration marshes, and Lake Ewauna. Analyses were restricted to cases where $>200$ larvae were sampled in a year and to size bins with a total sample size $>9$. Patterns of size-structured spatial distribution for each species for each year were visualized graphically with plots of the proportion of each size class in each major habitat.

\section{RESUlTS}

For each species, we defined small larvae as the lower $10 \%$ of the size distribution across all samples and summarized their distribution in major areas (Table 1). The smallest size classes of the 2 suckers were the most likely to be found in Upper Klamath Lake or the restoration marshes $(>96.7 \%)$ and least likely to be found in Lake Ewauna $(<1.6 \%)$. The smallest size classes of the 3 minnows were more variable, with small fathead minnows essentially ubiquitous outside the restoration marshes. Small tui chubs, like suckers, were most likely to be found in the lake, including Agency Lake, and the restoration marshes $(93.4 \%)$, while the smallest blue chubs were most likely to be found outside the lake in Lake Ewauna (63.3\%) and least likely to be found in restoration marshes (1.2\%) (Table 1). The site with the greatest number of small larvae, except blue chubs, was the mouth of the Williamson River, which had $61.5 \%$ of the shortnose suckers, $36.3 \%$ of the Lost River suckers, $19.1 \%$ of the fathead minnows, and $17.4 \%$ of the tui chubs. For blue chub, the 2 sites with the highest proportion of small larvae were both in Lake Ewauna.

Annual sample sizes for shortnose sucker larvae ranged from 258 in 2009 to 2059 in 2006. The proportion of the smallest shortnose sucker larvae was greatest at the mouth of the Williamson River or in Upper Klamath Lake, including 
Figure 3. Shortnose sucker
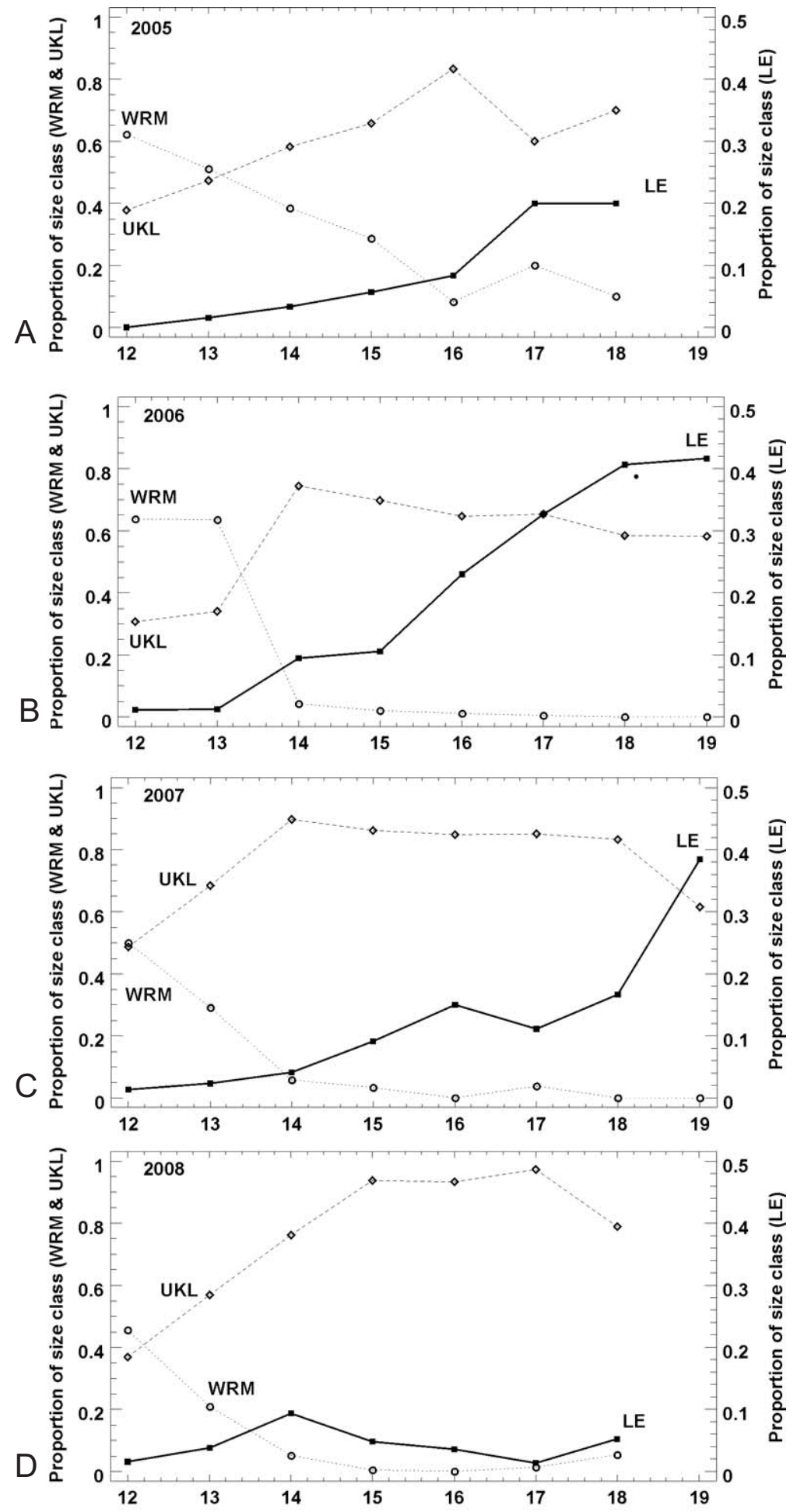


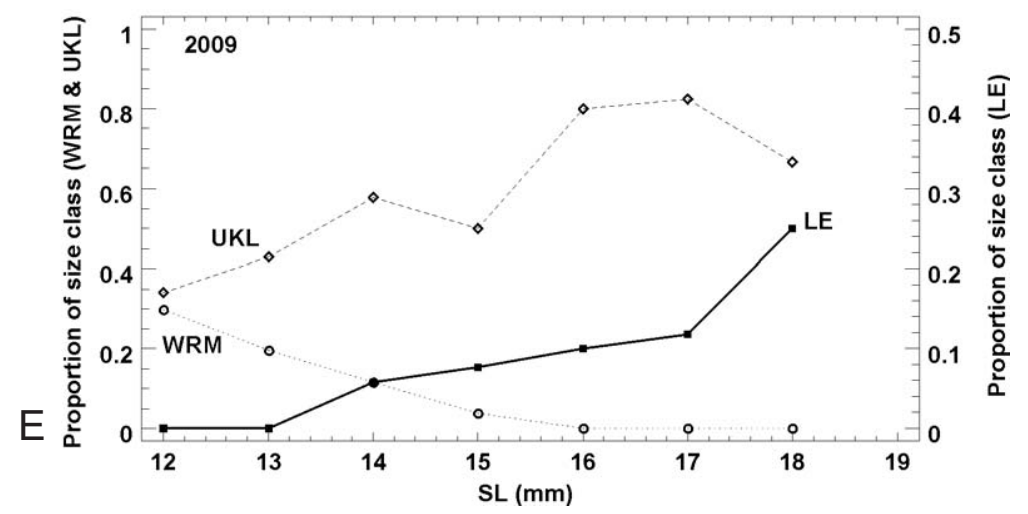

Fig. 3. Proportion of each size class of shortnose sucker collected in the Williamson River mouth, Upper Klamath Lake, and Lake Ewauna, Oregon, 2005-2009. UKL = Upper Klamath Lake including restoration marshes, WRM = Williamson River mouth, LE $=$ Lake Ewauna, SL = standard length. Note that LE data are scaled on the right axis. A, 2005; B 2006; C, 2007; D, 2008; E, 2009.

the restoration marshes (Fig. 3). As larval size increased, the proportion at the mouth of the Williamson River declined sharply and the proportion in Upper Klamath Lake and Lake Ewauna usually increased, such that the proportion in Lake Ewuana reached about 20\%-40\% in all years except 2008. Most years have weak spatial structuring of larger size classes; 2008 showed the strongest spatial structuring, with all size classes in the lake and few downstream. Although the proportion of small larvae was also low in Agency Lake (Table 1), there was no pattern of accumulation of larger larvae.

Annual sample sizes for Lost River sucker larvae were usually very low and were less than 200 in 2009 (that sample was dropped from further analysis); for the other years, sample sizes ranged from 205 (2007) to 330 (2006). The proportion of the smallest Lost River sucker larvae was also greatest at the Williamson River mouth or in Upper Klamath Lake, including the restoration marshes (Fig. 4). With increasing fish size, the patterns were complex but included at least a temporary increase of about $20 \%-40 \%$ in the proportion in Lake Ewauna. Most years had weak spatial size structuring, with larger size classes common in Upper Klamath Lake and downstream. As observed in shortnose sucker, the proportion of small larvae was also low in Agency Lake (Table 1), but there was no pattern of accumulation of larger larvae.

Annual sample sizes for tui chub larvae were $<200$ in 2005 and 2006 and were dropped from further analysis; for the other years, sample sizes ranged from 302 (2007) to 790 (2009). The greatest proportion of the smallest tui chub larvae was in Upper Klamath Lake, including the restoration marshes and Williamson River mouth (Fig. 5). With increasing fish size, the proportion in Lake Ewauna tended to increase, reaching about $40 \%$ in 2008 and 2009. Spatial size structuring was very strong in smaller size classes but often not in larger size classes.

Annual sample sizes for blue chub larvae ranged from 2328 (2008) to 9392 (2009). The highest proportion of the smallest blue chub larvae tended to be variable, either in Upper Klamath Lake, including the Williamson River mouth, or Lake Ewauna (Fig. 6). For size classes $>7 \mathrm{~mm}$, the proportion in each of these areas tended to stay relatively constant. In 2 years, 2005 and 2009, the proportion of larger size classes $(>15 \mathrm{~mm})$ in the restoration marshes increased to about $20 \%-40 \%$. In 2007, all size classes were mostly found in Upper Klamath Lake, with small proportions in restoration marshes or Lake Ewauna; however, in 2008 and 2009 , there were large proportions of multiple size classes in Lake Ewauna and, in 2009, in restoration marshes.

Annual sample sizes for fathead minnow larvae ranged from 324 (2005) to 7694 (2009). As with blue chubs, the highest proportion of the smallest fathead minnow larvae tended to be variable, either in Upper Klamath Lake, including the Williamson River mouth, or Lake Ewauna (Fig. 7). Except in 2009, for size classes $>10 \mathrm{~mm}$, the proportion in each of these areas tended to stay relatively constant. The proportion 

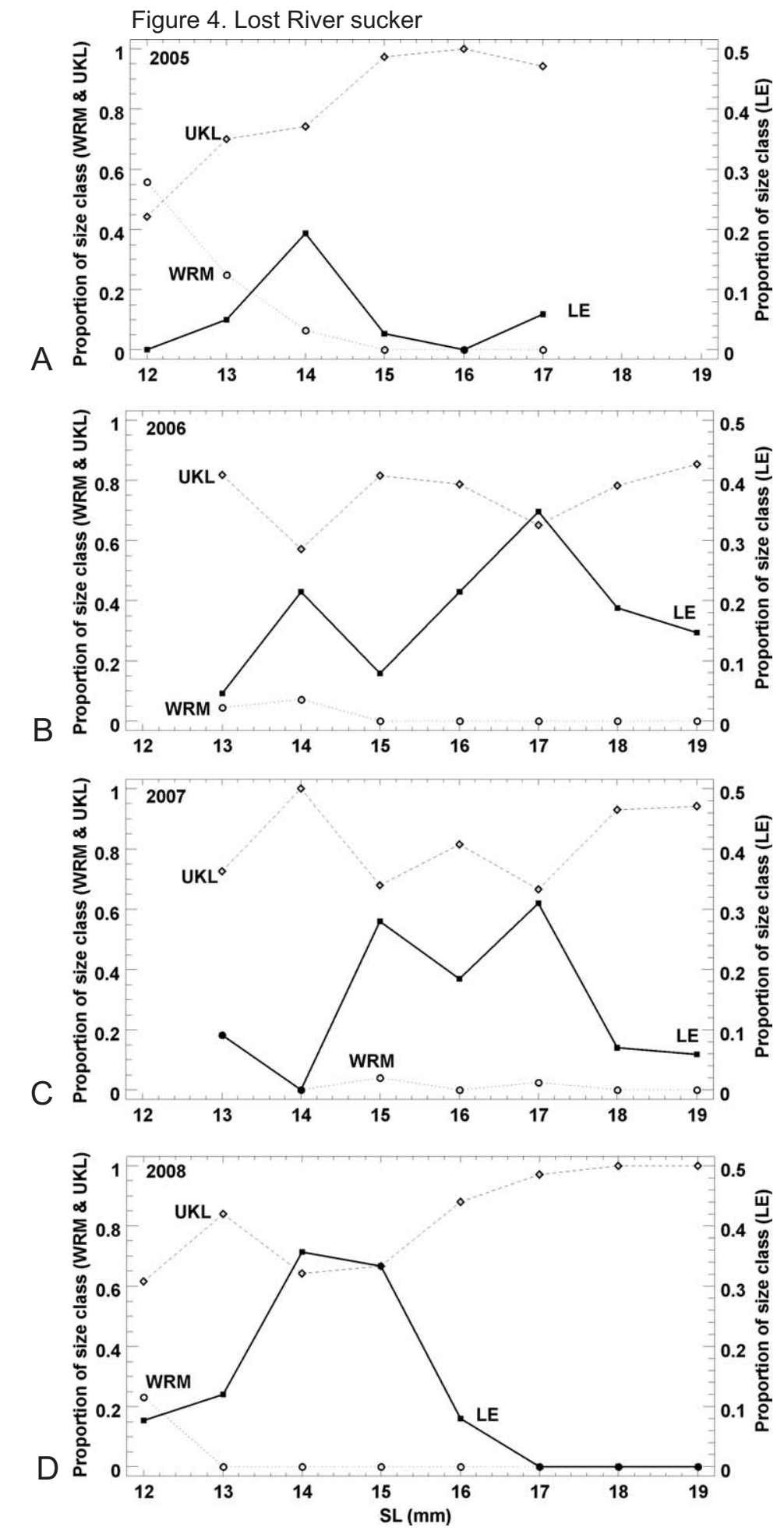

Fig. 4. Proportion of each size class of Lost River sucker collected in the Williamson River mouth, Upper Klamath Lake, and Lake Ewauna, Oregon, 2005-2009. UKL = Upper Klamath Lake including restoration marshes, WRM = Williamson River mouth, $\mathrm{LE}=$ Lake Ewauna, SL = standard length. Note that LE data are scaled on the right axis. A, 2005; B, 2006; C, 2007; D, 2008. 
Figure 5. Tui chub
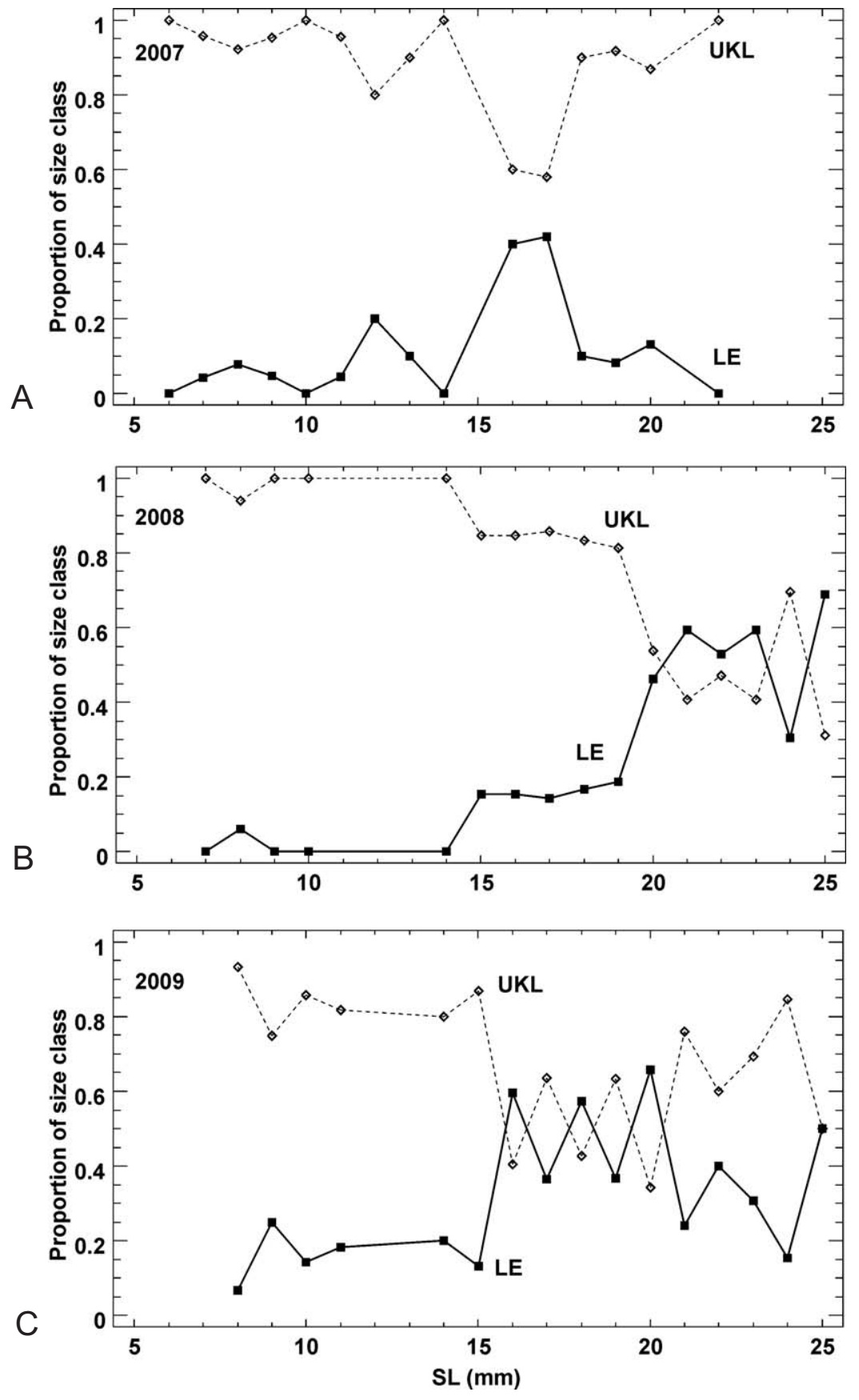

Fig. 5. Proportion of each size class of tui chub collected in Upper Klamath Lake and Lake Ewauna, Oregon, 2005-2009. UKL = Upper Klamath Lake including restoration marshes and the Williamson River mouth, LE $=$ Lake Ewauna, SL = standard length. A, 2007; B, 2008; C, 2009. 
Figure 6. Blue chub
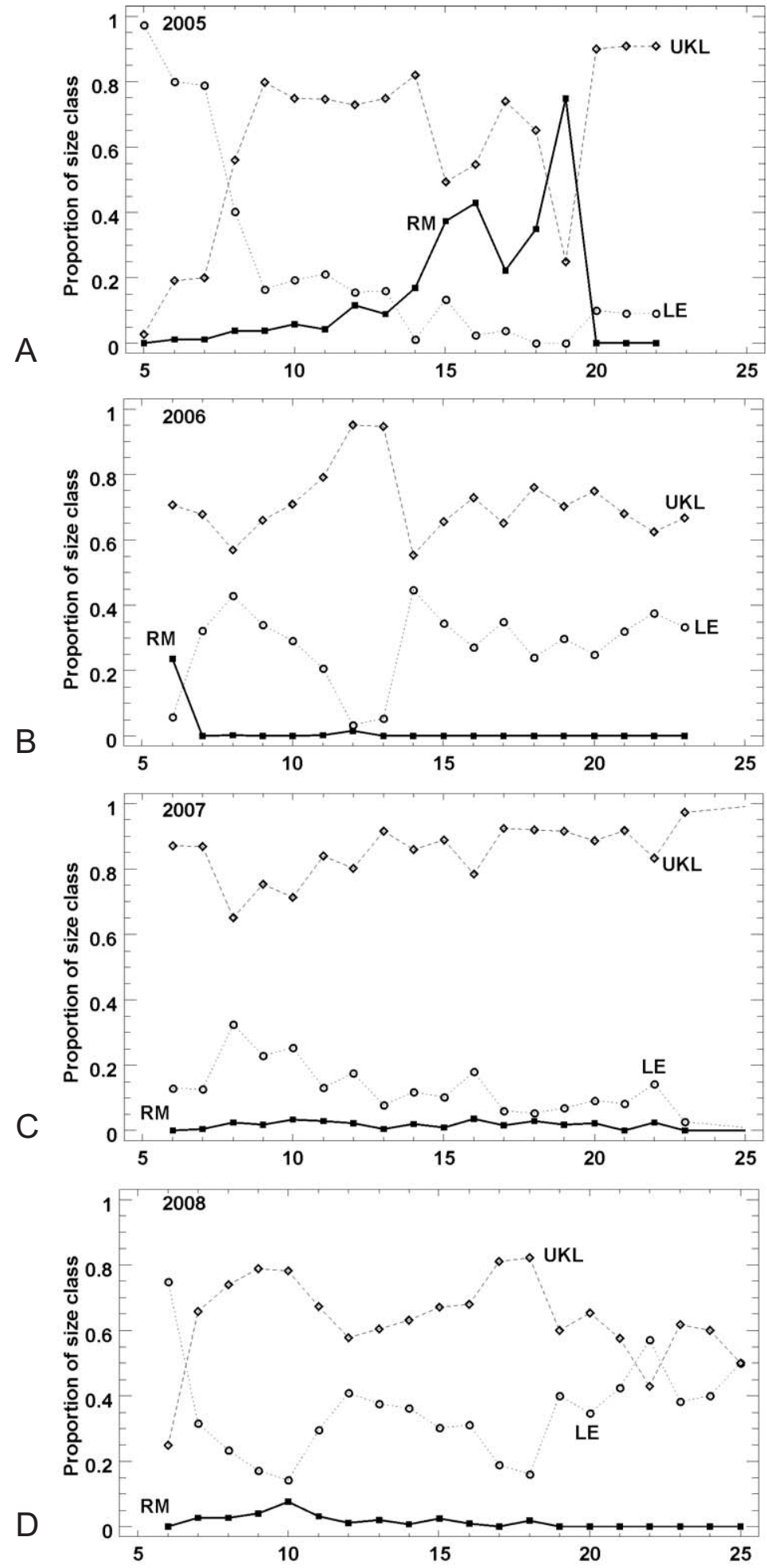


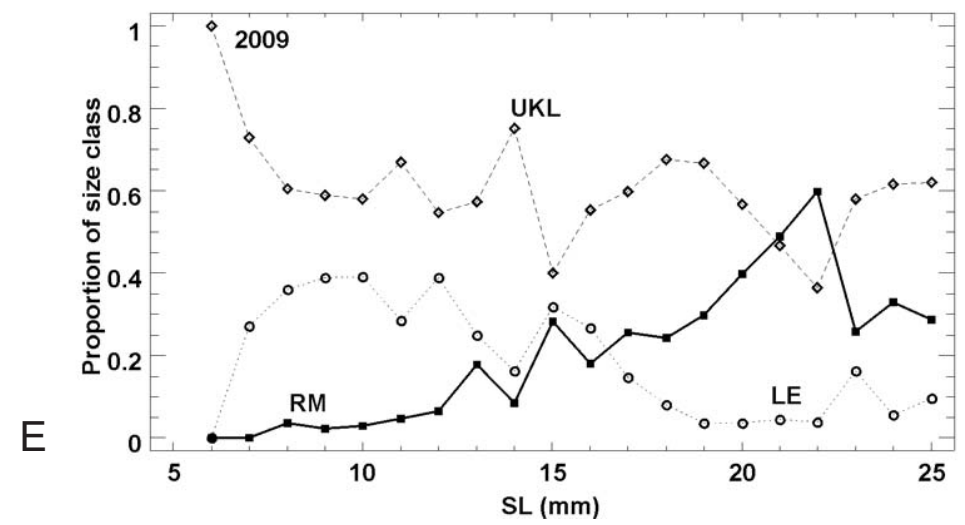

Fig. 6. Proportion of each size class of blue chub collected in restoration marshes, Upper Klamath Lake, and Lake Ewauna, Oregon, 2005-2009. UKL = Upper Klamath Lake including the Williamson River mouth, RM = restoration marshes, $\mathrm{LE}=$ Lake Ewauna, SL = standard length. A, 2005; B, 2006; C, 2007; D, 2008; E, 2009

Figure 7. Fathead minnow
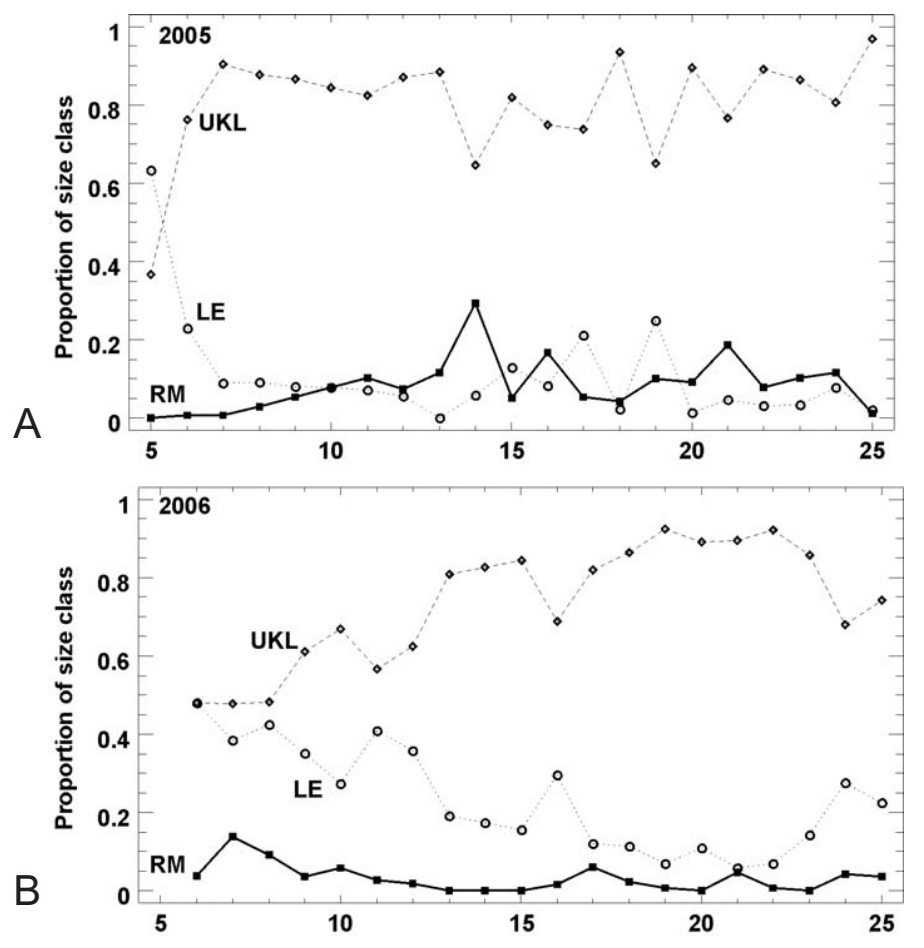

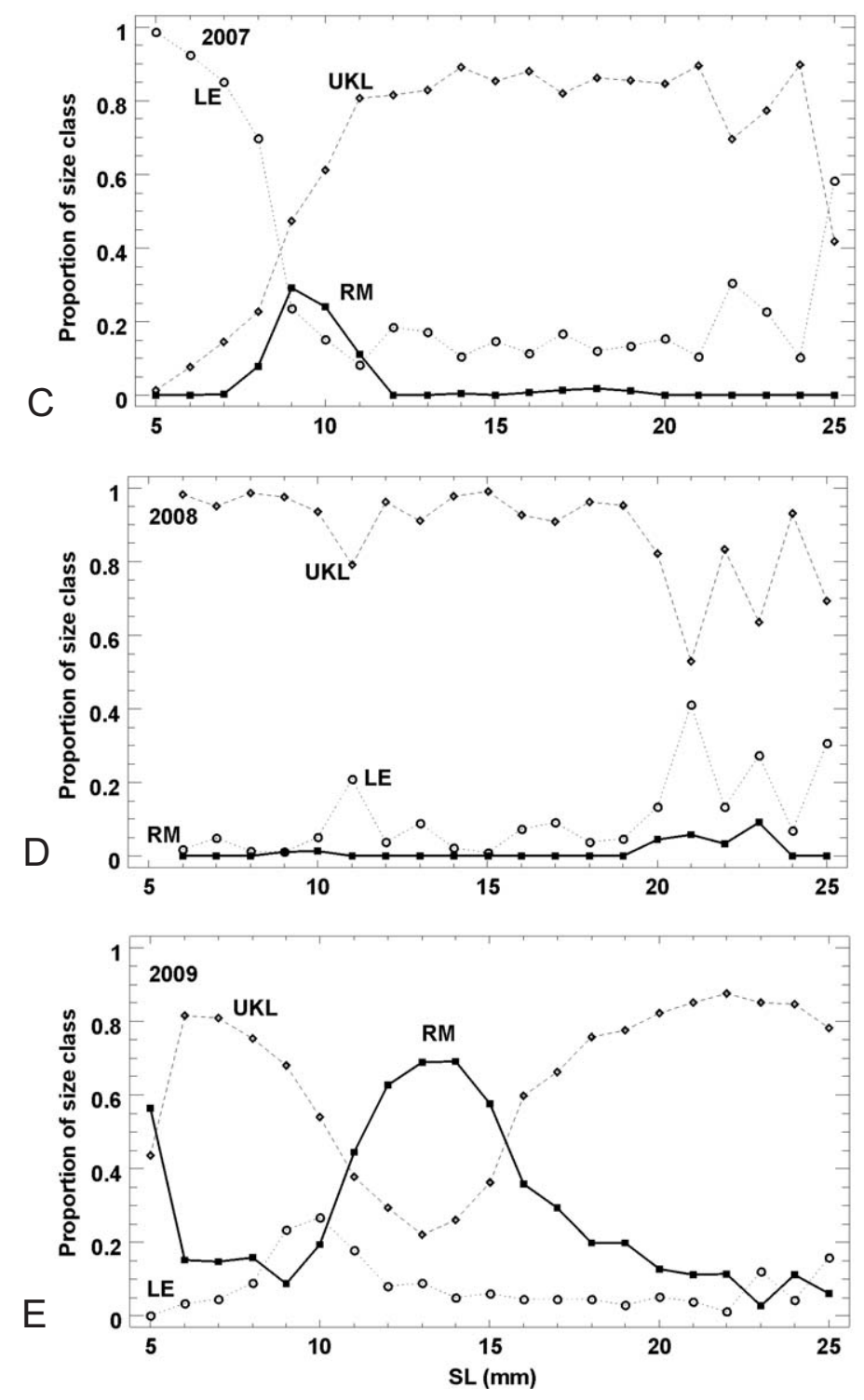

Fig. 7. Proportion of each size class of fathead minnows collected in restoration marshes, Upper Klamath Lake, and Lake Ewauna, Oregon, 2005-2009. UKL = Upper Klamath Lake including the Williamson River mouth, RM = restoration marshes, LE = Lake Ewauna, SL = standard length. A, 2005; B, 2006; C, 2007; D, 2008; E, 2009.

of larger size classes in the restoration marshes tended to be low $(<20 \%)$, except in 2009 , when the restoration marshes had $>50 \%$ of the 12 15-mm size classes.

Over the 5 years of the study, 222 of 624 sites had one or more of the values indicating poor water quality (water temperature $>21.9$ ${ }^{\circ} \mathrm{C}$, dissolved oxygen $<5.1 \mathrm{mg} \cdot \mathrm{L}^{-1}$, or $\mathrm{pH}>$ 8.9). All species were collected at sites with one or more of these values. Water quality was largely a function of season, with the last 2 sample surveys, conducted between 25 June and 24 July, having 173 (78\%) sites with one or more values indicating poor water quality. Species abundance was also season dependent; so to reduce the problem of cross-correlations with season, we examined selectivity of water quality by each of the 5 species for the last 2 survey periods. Strauss' linear index for selection of sites with good water quality ranged from -0.007 
to 0.087 , with $95 \%$ confidence intervals (CI) including zero for all species except shortnose sucker (index $=0.087, \mathrm{CI}=0.058-0.115)$.

\section{Discussion}

For all species, the smallest size classes were usually found at the mouth of the Williamson River. Restoration marshes also had many of the smallest size classes for both suckers and tui chubs, while the smallest blue chubs and fathead minnows were more broadly distributed. Vagrancy, as indicated by increasing proportions of mid- and larger size classes in Lake Ewauna, was obvious in some years for the suckers and tui chubs. Larger size classes of blue chub appeared to move into restoration marshes during 2 years of this study but avoid them in other years. Fathead minnows were predominantly found in Upper Klamath Lake but were generally ubiquitous for all size classes in all areas.

Movement of fish larvae is likely due to current dispersal mediated by volitional behavior. At some point in ontogeny, volitional behavior and responses to other cues, such as water quality, should begin to have a larger effect on spatial patterns. For the size ranges examined in this study, distributions tended to be random relative to water quality. During the last 2 surveys, when water quality was poorest, Strauss' linear index suggested that 4 of the species were distributed randomly with respect to water quality and not distributed based on avoidance of poor water quality. Only shortnose sucker had an index slightly but significantly greater than zero, suggesting that their distribution favored sites with better water quality. The index for all 5 species was very small and close to zero, indicating no strong avoidance or attraction based on the 3 water quality parameters examined. Other cues, such as feeding success and predation levels, could also affect behavior and influence spatial patterns, but their effects have not been explored.

An assumption of size-structured spatial patterns in larval dispersal is that spawning is spatially restricted, so we can infer that changes in frequencies of larger size classes in other areas is primarily due to movement of exogenous larvae into those areas. For both suckers, there is independent evidence that extant spawning areas are primarily in the Williamson/Sprague rivers and along eastern shoreline springs in Upper Klamath Lake (Markle and Cooperman
2002, Janney et al. 2008). For the other species, we cannot corroborate all spawning sites, but we might conclude from the distributions of small larvae (Table 1) that restoration marshes are relatively infrequently used for spawning by blue chubs or fathead minnows (Figs. 6, 7) and that Lake Ewauna is infrequently used for spawning by tui chubs (Fig. 5). Alternatively, spawning might be more widespread than the relative distribution of small larvae suggests, and the patterns may result from differential mortality in different areas. Spatial and temporal variation in mortality is almost certainly present but, as a first-order approximation, most researchers must usually assume that natural mortality is constant in space and time (Helbig and Pepin 1998a).

A related assumption of this study is that the larval trawl is equally efficient at capturing a size class of larva at all sites. This assumption is currently untested, but preliminary data suggest good efficiency for these species to 20-25 mm (unpublished data). Our fixed sites were chosen for access and spatial coverage, so we can make no strong inferences about the abundance of species in other areas. Another assumption is that length is related to age. For the size ranges we used, this assumption is certainly valid. Thus, relative to these fixed sites, it is valid to conclude that the proportion of small, younger shortnose sucker larvae is high at the mouth of the Williamson River every year and that the proportion of larger, older shortnose sucker larvae increases in the lake and restoration marshes every year. The proportion of larger shortnose sucker larvae increased in Lake Ewauna every year except 2008. Similar patterns were also seen in Lost River suckers and tui chubs. For blue chubs, the proportion of larger larvae increased in restoration marshes in some years (2005 and 2009) but not in others, as also happened with fathead minnows.

The relation between length and age and the importance of using ages should be considered if mortality and emigration rates are being estimated, as was done by Markle et al. (2009), or if finer-scale patterns are important. Growth in sucker larvae in Upper Klamath Lake, for example, is strongly temperature dependent (Terwilliger et al. 2003), so sucker larvae that reside in areas with higher temperatures should experience faster growth and be larger than counterparts in cooler areas. However, at the studied sizes, the expected difference in age of a 15-mm larva growing in cool temperatures in April 
and one growing in warm temperatures in July is only 5.1 days (Markle et al. 2009).

The increase in the proportion of larger sucker larvae in Lake Ewauna has been described in terms of the member-vagrant hypothesis (Markle et al. 2009). Markle et al. estimated rates and showed that, in one year, daily emigration from the lake was on the same order of magnitude as daily mortality. Here, membervagrant success is defined as retention in Upper Klamath Lake (including Agency Lake, restoration marshes, and the Williamson River mouth), and failure is defined as emigration to Lake Ewauna, where late summer water quality is especially poor (Sullivan et al. 2010). The present results show that interannual variation in vagrancy could be large. Member-vagrant success was relatively poor in 2006 , when $>30 \%$ of the 17-19-mm shortnose suckers were in Lake Ewauna (Fig. 3). Comparing 2006 and 2007, Wood (2009) noted contrasting wind patterns, with a strong reversal in late May and early June 2006. If retention is enhanced by wind reversals, we might have expected better retention in 2006, but our data did not show a reduction in the proportion of larger larvae in 2006 compared to 2007 (Fig. 3). Limitations of these data mean we cannot infer the absolute size of apparent movements, and relative size of movements should be considered first-order estimates.

The importance of assuming constant mortality in space and time further complicates interpretation if there are, in fact, spatial and interannual differences in mortality rates. We found no evidence of a water quality effect on distribution patterns, but it is possible that spatial and temporal differences in predator fields and preyrefuge habitats (Markle and Dunsmoor 2007) could create nonuniform mortality. For example, if wind reversal did retain more larvae in Upper Klamath Lake in 2006, but their mortality was higher than the mortality of vagrants in Lake Ewauna, the apparent relative increase in Lake Ewauna (Fig. 3) could result, in spite of a good retention mechanism in Upper Klamath Lake. Thus, success of the retention mechanism does not necessarily imply a successful final outcome. Crude approximations of larval mortality rate can be derived from empirical relationships with growth rates, such as the relationship derived for marine larvae by Houde and Bartsch (2009). These or more rigorous estimates need to be a routine part of analyses of larval spatial patterns.
A successful final outcome is also dependent on production. A large year class with large emigration may produce more total juveniles in the lake than a small year class with little or no emigration. When the population abundance is low, there is also likely a greater uncertainty in estimates, both of relative changes, as described here, and absolute changes.

Although the sampling reported here was spatially extensive so that losses from the lake could be detected (Houde and Bartsch 2009), potential losses through the "A" Canal were not detectable. If larval emigration through Link River and the "A" Canal are proportional to volume, then the "A" Canal loss could be estimated.

Further progress in understanding the effects of circulation on larval retention and loss from Upper Klamath Lake should include field validation of predictions from circulation models (Wood et al. in press). Validation can include the fixed-site sampling used herein, but more rigorous estimates of the absolute abundance of a size class in an area require a different sampling strategy that includes random sampling of all suitable habitat and quantification of size vulnerability. Pepin et al. (2009) suggested adaptive sampling as the appropriate sampling strategy. Most adaptive sampling programs require field-based decisions in which organisms are identified and counted and subsequent sampling decisions made in the field based on prior samples. This approach would be difficult with larvae in almost any system, unless a "pre-survey" was used to make decisions. Pepin et al. (2009) also noted, "Regional circulation models, forced by long-term series of wind observations, can be used to assess the range of probable drift and dispersal patterns, which can then be used to identify an optimal survey design to meet the programme's objectives." If sampling is therefore adapted to the circulation model, the model of Upper Klamath Lake suggests larval retention occurs when larvae are entrained in a wind-generated gyre or when their transport is slowed by marshes or other shoreline irregularities (Markle et al. 2009, Wood 2009). Coupled with the spatial patterns identified herein, key areas for understanding sucker larval retention and loss from the lake include the source or input area near the Williamson River mouth, retention and transport areas within $1 \mathrm{~km}$ of the eastern and southern shoreline, retention areas of marshes, retention 
area(s) of the central gyre, and downstream loss in Lake Ewauna and the "A" Canal.

Spatial patterns of larval and juvenile fishes are due to both extrinsic and intrinsic factors, and both types of factors should change with ontogeny. For example, loss of older life history stages from the lake may have little to do with prevailing currents and be more dependent on water quality or other factors. This study suggests that some spatial patterns for larvae and early juveniles of some fish species in Upper Klamath Lake may be due, in part, to the interaction of their intrinsic behavior with prevailing currents. These currents can result in retention or loss from Upper Klamath Lake. Unfortunately, we know very little about the behaviors or their ontogeny and cues. Factors that trigger a larva to drift at night or hold its position in a favored area are largely speculative. However, a purpose of this exercise was to show that mapping spatial patterns over the relatively small size range of fish larvae can help demonstrate vagrancy. If a management goal is to reduce vagrancy and retain more larvae in Upper Klamath Lake, then actions such as marsh restoration adjacent to the eastern boundary current and establishment of spawning areas distant from the lake outlet should be effective.

\section{ACKNOWLEDGMENTS}

Specimen collections were authorized under USFWS Scientific Taking Permit TE 006333-10 (OSU) and OSU Institutional Animal Care and Use permits LAR-2162 and LAR-3619. Dave Simon and Mark Terwilliger led field collections and data management with student assistants Sara Akins, G. Antonio Cordero, Jenna Gelardi, Jake Godfrey, Kirsten Heesacker, Cara Holem, Justin Huff, Mark Jansen, Thomas Litwin, Elizabeth Quimba, Tamal Reece, Autumn Smith, Kate Spangler, Kevin Stertz, and Dax Strubb. This paper benefitted from discussions with S. Burdick, C. Ellsworth, H. Henderson, and T. Wood. A helpful review of this manuscript was provided by S. Burdick. This report was funded by the Bureau of Reclamation (Reclamation), U.S. Department of Interior, as part of Reclamation's mission to manage, develop, and protect water and related resources in an environmentally and economically sound manner in the interest of the American public. Funding was provided through contract R09AC20029. The views in this report are the author's and do not necessarily represent the views of Reclamation.

\section{Literature Cited}

Brown, A.V., And M.L. Armstrong. 1985. Propensity to drift downstream among various species of fish. Journal of Freshwater Ecology 3:3-17.

CoOperman, M.S., AND D.F. MARKLE. 2003. Rapid outmigration of Lost River and shortnose sucker larvae from in-river spawning beds to in-lake rearing grounds. Transactions of the American Fisheries Society 132: 1138-1153.

Helbig, J.A., AND P. PePin. 1998a. Partitioning the influence of physical processes on the estimation of ichthyoplankton mortality rates. I. Theory. Canadian Journal of Fisheries and Aquatic Sciences 55: 2189-2205.

1998b. Partitioning the influence of physical processes on the estimation of ichthyoplankton mortality rates. II. Application to simulated and field data. Canadian Journal of Fisheries and Aquatic Sciences 55:2206-2220.

HoudE, E.D. 1997. Patterns and trends in larval stage growth and mortality of teleost fish. Journal of Fish Biology 51 (Supplement A):52-83.

2002. Mortality. Pages 64-87 in L.A. Fuiman and R.G. Werner, editors, Fishery science: the unique contributions of early life stages. Blackwell Science, Oxford.

Houde, E., AND J. Bartsch. 2009. Mortality. Pages 27-42 in E.W. North, A. Gallego, and P. Petitgas, editors, Manual of recommended practices for modelling physicalbiological interactions during fish early life. ICES Cooperative Research Report 295.

Janney, E.C., R.S. Shively, B.S. Hayes, and P.M. Barky. 2008. Demographic analysis of Lost River sucker and shortnose sucker populations in Upper Klamath Lake, Oregon. Transactions of the American Fisheries Society 137:1812-1825.

LaBolle, L.D., JR., H.W. Li, and B.C. Mundy. 1985. Comparison of two samplers for quantitatively collecting larval fishes in upper littoral habitats. Journal of Fisheries Biology 26:139-146.

Markle, D.F., M.R. Cavalluzzi, and D.C. Simon. 2005. Morphology and taxonomy of Klamath Basin suckers (Catostomidae). Western North American Naturalist 65:473-489.

Markle, D.F., and M. Cooperman. 2002. Relationships between Lost River and shortnose sucker biology and management of Upper Klamath Lake. Pages 93-117 in W.S. Braunworth Jr., T. Welch, and R. Hathaway, editors, Water allocation in the Klamath Reclamation Project, 2001: an assessment of natural resource, economic, social, and institutional issues in the Upper Klamath Basin. Oregon State University Extension Service, Corvallis, OR. 401 pp.

Markle, D.F., AND L.K. DunsmoOR. 2007. Effects of habitat volume and fathead minnow introduction on larval survival of two endangered sucker species in Upper Klamath Lake, Oregon. Transactions of the American Fisheries Society 136:567-579.

Markle, D.F., S.A. Reithel, J. Crandall, T. Wood, T.J. Tyler, M. Terwilliger, and D.C. Simon. 2009. Larval fish transport and retention, and the importance of location for juvenile fish recruitment 
in Upper Klamath Lake, Oregon. Transactions of the American Fisheries Society 138:328-347.

Pavlov, D.S. 1994. The downstream migration of young fishes in rivers: mechanisms and distribution. Folia Zoologica 43:193-208.

Pepin, P., C. Werner, and J. van der Molen. 2009. Application 1: adaptive sampling. Pages 60-62 in E.W. North, A. Gallego, and P. Petitgas, editors, Manual of recommended practices for modelling physicalbiological interactions during fish early life. ICES Cooperative Research Report 295.

РоттноF, T. 1984. Clearing and staining techniques. Pages 35-37 in H.G. Moser, editor-in-chief, Ontogeny and systematics of fishes. Special Publication No. 1, American Society of Ichthyologists and Herpetologists, Lawrence, KS.

REMPLE, S., AND D.F. MARKLE. 2005. Description and identification of larval cyprinids (fathead minnow, tui chub and blue chub) from Upper Klamath Lake, Oregon. California Fish and Game 91(2):83-99.

Ryквоsт, K.A., AND R. TodD. 2002. An overview of the Klamath Reclamation Project and related Upper Klamath Basin hydrology. Pages 45-73 in W.S. Braunworth Jr., T. Welch, and R. Hathaway, editors, Water allocation in the Klamath Reclamation Project, 2001: an assessment of natural resource, economic, social, and institutional issues in the Upper Klamath Basin. Oregon State University Extension Service, Corvallis, OR. $401 \mathrm{pp}$.

SinCLAIR, M. 1988. Marine populations: an essay on population regulation and speciation. University of Washington, Seattle, WA.

StRauss, R.E. 1983. Reliability estimates for Ivlev's electivity index, the forage ration, and a proposed linear index of food selection. Transactions of the American Fisheries Society 108:344-352.
Sullivan, A.B., D.M. Snyder, and S.A. Rounds. 2010. Controls on biochemical oxygen demand in the upper Klamath River, Oregon. Chemical Geology 269:12-21.

TAGGaRT, C.T., AND W.C. LEGGETT. 1987. Short-term mortality in post-emergent larval capelin Mallotus villosus. I. Analysis of multiple in situ estimates. Marine Ecology Progress Series 41:205-217.

Terwilliger, M., D.F. MarkLE, and J. Kann. 2003. Associations between water quality and daily growth of juvenile shortnose and Lost River suckers in Upper Klamath Lake, Oregon. Transactions of the American Fisheries Society 132:691-708.

Wood, T.M. 2009. Preliminary study of the effect of the proposed Long Lake Valley Project operation on the transport of larval suckers in Upper Klamath Lake, Oregon. U.S. Geological Survey Open-File Report 2009-1060. Available from: http://or.water.usgs.gov/ klamath/publications.html

Wood, T.M., R.T. Cheng, J.W. Gartner, G.R. Hoilman, M.K. LindenberG, and R.E. Wellman. 2008. Modeling hydrodynamics and heat transport in Upper Klamath Lake, Oregon, and implications for water quality: U.S. Geological Survey Scientific Investigations Report 2008-5076. Available from: http://pubs.usgs .gov/sir/2008/5076/.

Wood, T.M., S. Burdick, C. Erdman, H. Hendrixson, D.F. Markle, C. Ellsworth, and N. Buccola. In press. Modeling the transport of larval suckers through the Williamson River Delta, Upper Klamath Lake, Oregon, using a density and individual-based approach. U.S. Geological Survey Open-File Report.

Received 8 September 2010 Accepted 20 May 2011 